\title{
José Mário Pires Azanha: a radicalidade de uma razão apaixonada
}

Nílson José Machado

Universidade de São Paulo

Não era um homem simples. Nada nele era previsivel, exceto, talvez, a radicalidade de seu pensamento, a percuciência de sua argumentação, a intensa paixão na defesa de seus pontos de vista e a freqüência com que se envolvia em polêmicas, sempre imbuído, a seu juízo, dos mais altos ideais de justiça, do mais genuíno espírito público. Notável era sua competência em transformar todas essas circunstâncias em textos agudos, da melhor qualidade, extremamente bem redigidos.

Era um mestre no uso da palavra, sobretudo da palavra escrita. Sua retórica parecia, às vezes, dura, mas era sempre muito eficiente, muito esclarecida, muito precisa. Em razão de suas indiscutíveis qualidades intelectuais, certamente era mais respeitado que temido, mas era temido, sem dúvida, o era. Não era fácil enfrentálo num debate; sua argumentação era verdadeiramente fulminante.

Fui seu orientando no doutorado, entre 1985 e 1988, período em que convivemos intensamente, em atividades acadêmicas e nãoacadêmicas. Sua generosidade fez com que, nesse período, me acolhesse como um verdadeiro discípulo, ou mesmo como um filho.

Aprendi muito com a profundidade de seu conhecimento, com a amplitude de suas leituras, com a universalidade de seus interesses. Da educação à filosofia, da política à estética, da antropologia à culinária, nenhuma dimensão do modo de ser do ser humano the era indiferente. Com ele, todos os temas poderiam constituir-se em objetos de uma reflexão densa, sempre apaixonada, sempre reveladora.

Sua independência intelectual era admirável. Impossível classificá-lo em qualquer dos "ismos" que povoam - e, às vezes, infestam o cenário acadêmico: positivismo, marxismo, construtivismo, estruturalismo, personalismo, evolucionismo, conservadorismo, etc., etc., etc. Nenhum rótulo era capaz de representá-lo.

Ao longo de sua operosa existência, construiu uma biblioteca pessoal muito especial, um verdadeiro tesouro para estudiosos de diferentes estirpes. Seus livros, mapeados por notas agudas em quase todas as páginas, revelam com nitidez a altivez com que dialogava com os autores, bem como o vigor de seu pensamento.

Suas inúmeras e indiscutiveis qualidades intelectuais e suas caracteristicas pessoais compunham, naturalmente, uma personalidade bastante complexa. Era extremamente exigente, sobretudo consigo mesmo. Em razão disso, ainda que nos tenha legado uma obra escrita respeitável, publicou muito menos do que teria condições de fazê-lo. Embora seu vigor intelectual certamente animasse seus orientandos, algumas vezes, seu nível de exigência assustava os discípulos mais incipientes. Sempre tive a certeza, no entanto, da sinceridade de suas intenções, ao entusiasmar ou arrefecer os ânimos na justa medida.

É, ele não era um homem simples, não era simples compreendê-lo, ou mesmo aceitar alguns de seus pontos de vista mais caros, sempre plenos de uma radicalidade que somente os espíritos independentes e criativos podem alcançar. Mas era um ser humano notável, um intelectual fecundo como poucos, um professor, um mestre no sentido pleno da palavra.

Infelizmente, deixou-nos muito cedo. Certamente, sentiremos muito sua falta. 